\author{
Igor Yu. Matyushenko \\ V.N. Karazin Kharkiv National University, \\ School of International Economic Relations and Travel Business \\ app. 380, 6 Svobody Sq., 61022 Kharkiv, Ukraine, imatyushenko@karazin.ua \\ (i) https://orcid.org/0000-0001-9866-9025 \\ Olesia V. Azarenkova \\ V.N. Karazin Kharkiv National University, \\ School of International Economic Relations and Travel Business \\ app. 380, 6 Svobody Sq., 61022 Kharkiv, Ukraine, azarenkova.olesia@gmail.com
}

\title{
PROSPECTS OF CONVERGENT TECHNOLOGIES USAGE IN SOLVING THE GLOBAL ENERGY PROBLEM
}

\begin{abstract}
The article summarizes the main findings regarding a study on global problems, with an emphasis on global energy problems and possible solutions. To find solutions to global problems, the conditions of the new industrial revolution were taken into account, the features of technological development of economies in countries worldwide were investigated and, namely the essence of economic paradigms aimed at solving global problems was determined. Convergence of NBIC-technologies as a key factor of the new industrial revolution were characterized, and the process of converging knowledge, technologies and society as a mechanism for solving global problems was studied. Trends in the development of scientific and technical, innovative activities in Ukraine and countries worldwide were determined. In particular, the main directions for development of converging and advanced production technologies that are most promising for developed countries, developing countries and Ukraine are presented.
\end{abstract}

\section{Key words}

biotechnology, biofuels, convergent technologies, global energy problem, nuclear energy, alternative energy, energy security, thermonuclear energy

\section{Introduction}

The most significant trend that has shaped the face of the world since the turn of this century has been the formation of a global economic system that erases the boundaries of national economies and which is bound by strong trade, financial, political, social and cultural relations. In the second half of the twentieth century mankind faced many severe global problems. These included processes and phenomena that cover the sphere of interaction between nature and society, as well as relations between worldwide social communities - peoples and states. The need to find solutions to mankind's global problems has been generated by threats of a highly dangerous nature that put the further existence of mankind in peril. After the economic crisis of 2008-2009, the most developed countries of the world considered convergent technologies as the main tool for solving global problems, based on the mutual influence and mutual penetration of the constituent parts of these technologies (foremost nano-, bio-, informational and cognitive technologies). The scientific tasks of using convergent technologies to solve global problems have been studied by O. Sartakova [1], K. McCormick, N. Kautto [2], D. Yergin, I. Buntov, V. Khaustova, etc. [3-16] and other researchers.

\section{Method of research}

Content analysis and bibliographic retrieval were used as the main methods of research, which allowed making a meaningful analysis of classic papers and works of modern economists devoted to studying Ukrainian trends in convergent technologies' scientific research. General scientific methods make up a methodological foundation of the research. They include description, comparison, statistical reviews, system analysis and others, which help characterize this phenomenon's development in a more comprehensive way. The methods of dialectic cognition, structural analysis and principles of logic which allow making authentic conclusions regarding the investigated topic were also applied. Official statistical data of state institutions and international organizations, publications of reference character, analytical monographs, annual statistical bulletins, World and Ukrainian institutions and universities' reports all served as the information basis for the research. 


\section{Results and Discussion}

The term "global problems" was first used in scientific research by scientists of the Rome Club in the 1960s and such general global problems have the following essential features:

- they concern not only individuals, but all of mankind;

- they cannot be solved by individual countries, but require a purposeful and organized effort by the entire world community;

- they are closely related to each other, cover all aspects of people's lives, and therefore require a comprehensive solution [14].

Over the past 50 years, a large number of foreign and domestic scientists have devoted their studies to these problems and their corresponding transformation and influence on the development of particular countries. On the basis of modern studies by Ukrainian scholars, the main global problems that relate first of all to the material sphere can be combined into the following four groups:

- depopulation and aging of the population;

- lack of food and the exhaustion of stocks of a number of raw materials and fuels;

- environmental problems, new energy and energy saving;

- slowing down of scientific and technological progress and lagging behind the leading countries of the world in the transition to a new technological structure (Figure 1) [9-11].

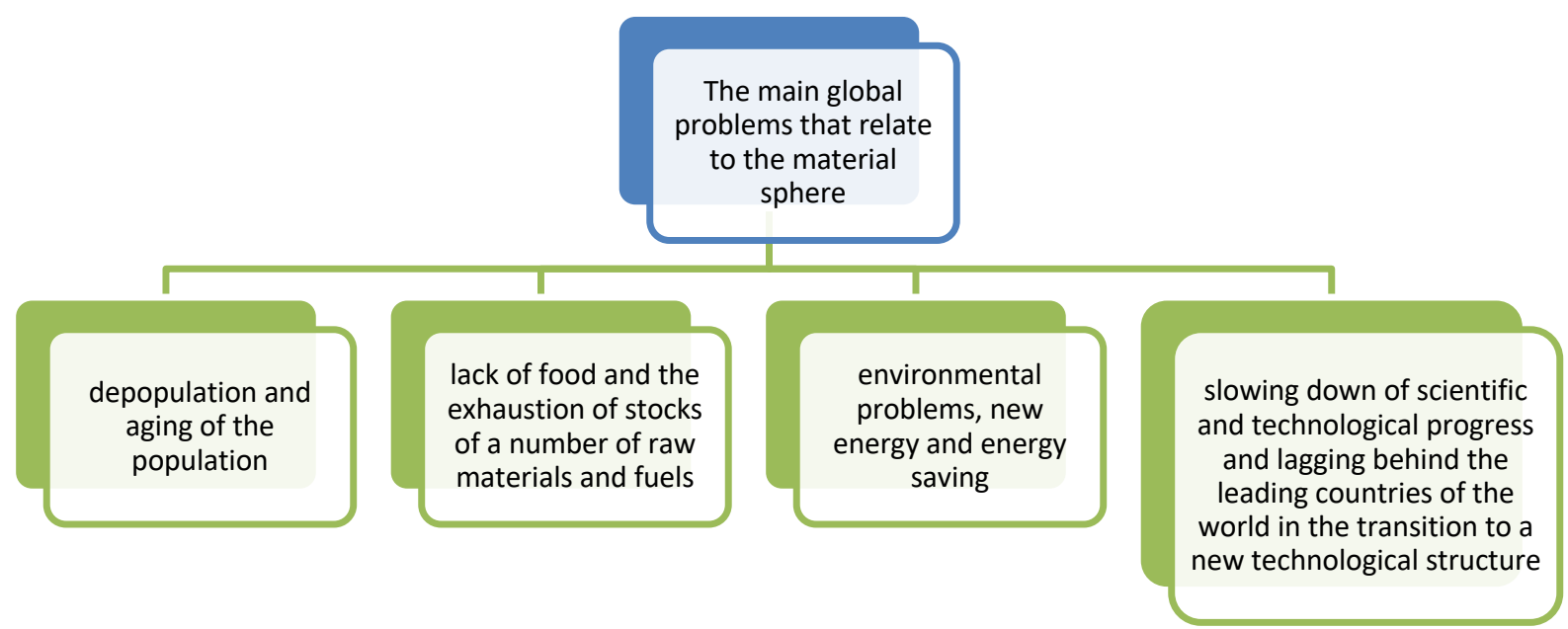

Figure 1. The main global problems that relate to the material sphere Source: [9-11]

The energy problem is definitely counted in the category of being of global concern. Its research should take into account the level of development of science, technology, economics, social relations and the specifics of the interaction of energy supply and economic growth. This approach avoids narrow-minded estimates and unreasonable generalizations used to distinguish between techno-economic, social and other groups of factors increasing and exacerbating the energy problem, the differentiation of its manifestations for particular periods, groups of countries and industries are covered. Above all, there has been a general deterioration of the natural and geographical conditions for the continued extraction of mineral fuels and, as a consequence, a significant increase in the cost of exploration, extraction and transportation of energy over long distances. Areas of oil and gas supplies are becoming increasingly distanced from the main centers of their consumption. Satisfaction of rapidly growing energy needs is still carried out extensively - involving in the circulation of new energy resources and their costs which are not always justified. Overall, the transition to energy-saving technologies is limited to the wealthiest nations. In the vast majority of developing countries, this process, which requires a significant amount of investment, is delayed. An important factor in the globalization of the energy problem is its close connection, both direct and indirect, with other global problems the world now faces. Modern energy is mainly based on non-renewable energy sources, which, with limited resources, are exhaustive and cannot guarantee the sustainable development of the world energy supply over the long term, and their use is one of the main factors that has led to the crisis in deterioration of the environment. There is an increase in the total world consumption of primary energy, mainly due to the constant growth of the world's population and increase in specific energy consumption. Today a reliable energy supply is one of the most significant factors for stable economic development. The quality and uninterrupted operation of energy supplies depends on the level of 
energy service provided the population, the country's national security and global security in general. The Global Energy Institute's (GEI) International Index of Energy Security Risk provides a look at energy security risks across different countries for the years 1980 through 2016; it is calculated for 25 countries that make up the Index's large energy user group. Norway remained the most energy secure country among the large energy user group in 2016, a position it has held since it took over first place from the United Kingdom in 2006. Unfortunately, Ukraine continues its unbroken record (since 1992) of being the least energy secure country among the large energy user group [28].

The key challenges for energy security include:

- energy intensity, that is, how much energy is spent on production of a unit of GDP;

- natural gas imports - this risk has intensified for most countries that are large consumers of energy. This is due to the fact that the increase of gas extraction, with the exception of the USA, is observed only in countries with high political risks, as well as the fact that the needs of gas in developed countries are increasing;

- volatility of prices and supplies of oil and petroleum products.

Modern researchers and international organizations [14] traditionally distinguish three main criteria for assessing the degree of manifestation of the global energy problem:

- ACCESSIBILITY - the degree to which people have access to modern and affordable energy;

- AVAILABILITY - the reliability and security of energy supply systems, as well as the rather high degree of infrastructure development;

- ACCEPTABILITY - environmental safety of production, transportation and consumption of energy.

Proceeding from the foregoing, one can distinguish the main levels of the manifestation of the global energy problem (Figure 2):



Figure 2. Levels of the global energy problem Source: Author's

When identifying Ukraine's position in comparison to other top energy-consuming countries, it is obvious that Ukraine is extremely dependent on imports of energy products. Ukraine ranks last among 25 countries - large consumers of energy in terms of the energy intensity and energy consumption (see Table 1). 
Table 1. Energy efficiency indices for top energy consuming countries, 2016

\begin{tabular}{|c|c|c|c|}
\hline Index & $1^{\text {st }}$ place & $25^{\text {th }}$ place & Ukraine \\
\hline Risk Score & Norway & Ukraine & 25 \\
\hline $\begin{array}{l}\text { Petroleum Import } \\
\text { Exposure }\end{array}$ & Canada & Japan & 16 \\
\hline $\begin{array}{l}\text { Natural Gas Import } \\
\text { Exposure }\end{array}$ & Australia & France & 16 \\
\hline Coal Import Exposure & Australia & Netherlands & 15 \\
\hline $\begin{array}{l}\text { Total Energy Import } \\
\text { Exposure }\end{array}$ & Canada & Japan & 17 \\
\hline $\begin{array}{l}\text { Fossil Fuel Import } \\
\text { Expenditures per GDP }\end{array}$ & Canada & Ukraine & 25 \\
\hline
\end{tabular}

Source: [29]

Ukraine has low rates in the category of volatility of prices and markets, which means that it is not able to operate and reduce risks to the economy from changes in energy prices. This makes enterprises very sensitive to changes in gas, electricity or oil prices. (see Table 2).

Table 2. Energy expenses and prices influence

\begin{tabular}{|c|c|c|c|c|}
\hline Metrics & Index & $1^{\text {st }}$ place & $25^{\text {th }}$ place & Ukraine \\
\hline \multirow[t]{3}{*}{$\begin{array}{l}\text { Energy Expenditure } \\
\text { Metrics }\end{array}$} & $\begin{array}{l}\text { Energy Expenditure } \\
\text { Intensity }\end{array}$ & UK & Ukraine & 25 \\
\hline & $\begin{array}{l}\text { Energy } \\
\text { Expenditures per } \\
\text { Capita }\end{array}$ & India & Netherlands & 7 \\
\hline & $\begin{array}{l}\text { Retail Electricity } \\
\text { Prices }\end{array}$ & South Africa & Italy & 14 \\
\hline \multirow[t]{2}{*}{$\begin{array}{l}\text { Price \& Market } \\
\text { Volatility Metrics }\end{array}$} & $\begin{array}{l}\text { Energy Expenditure } \\
\text { Volatility }\end{array}$ & UK & Ukraine & 25 \\
\hline & GDP per Capita & Norway & India & 24 \\
\hline
\end{tabular}

Source: [29]

Compared to other top energy consuming countries, Ukraine has sufficient diversification in the electricity market. Regarding electricity, it should be noted that the problem in the electricity market is not the lack of energy resources to ensure energy, but rather imperfect tariff and regulatory policies, domestic monopolies and ageing of power grids (see Table 3).

Table 3. Energy Use Intensity and Electricity Power Sector

\begin{tabular}{|l|l|l|l|l|}
\hline Metrics & Index & $\mathbf{1}^{\text {st }}$ place & $\mathbf{2 5}^{\text {th }}$ place & Ukraine \\
\hline $\begin{array}{l}\text { Energy Use } \\
\text { Intensity Metrics }\end{array}$ & $\begin{array}{l}\text { Energy } \\
\text { Consumption per } \\
\text { Capita }\end{array}$ & India & Canada & 9 \\
\cline { 2 - 5 } & Energy Intensity & Denmark & Ukraine & 25 \\
\cline { 2 - 5 } & Petroleum Intensity & Germany & Thailand & 22 \\
\hline $\begin{array}{l}\text { Electricity Power } \\
\text { Sector Metrics }\end{array}$ & $\begin{array}{l}\text { Electricity Capacity } \\
\text { Diversity }\end{array}$ & Spain & Norway & 8 \\
\cline { 2 - 5 } & $\begin{array}{l}\text { Non-Carbon } \\
\text { Generation }\end{array}$ & Norway & Indonesia & 8 \\
\hline
\end{tabular}

Source: [29]

Although Ukraine ranks on the top of the rating in terms of transport costs per capita and $\mathrm{CO} 2$ emissions, it is nearly last place in terms of energy intensity of transport and emission intensity (see Table 4). 
Table 4. Transport and Ecology

\begin{tabular}{|l|l|l|l|l|}
\hline Metrics & Index & $\mathbf{1}^{\text {st }}$ place & $\mathbf{2 5}^{\text {th }}$ place & Ukraine \\
\hline \multirow{2}{*}{$\begin{array}{l}\text { Sransportation } \\
\text { Sector Metrics }\end{array}$} & $\begin{array}{l}\text { Transport Energy } \\
\text { per Capita }\end{array}$ & India & USA & 2 \\
\cline { 2 - 5 } & $\begin{array}{l}\text { Transport Energy } \\
\text { Intensity }\end{array}$ & Japan & Ukraine & 23 \\
\cline { 2 - 5 } & $\mathrm{CO}_{2}$ Emissions & Denmark & Indonesia & 9 \\
\hline \multirow{2}{*}{$\begin{array}{l}\text { Environmental } \\
\text { Metrics }\end{array}$} & $\mathrm{CO}_{2}$ per Capita & India & Canada & 4 \\
\cline { 2 - 5 } & $\mathrm{CO}_{2}$ GDP Intensity & Denmark & Russia & 24 \\
\hline
\end{tabular}

Source: [29]

To guarantee high level of energy security, i.e. the state in which the country, its economy and population will have uninterrupted availability of energy sources at an affordable price it is required to use the most prospective energy technologies (see Fig.3) [8].

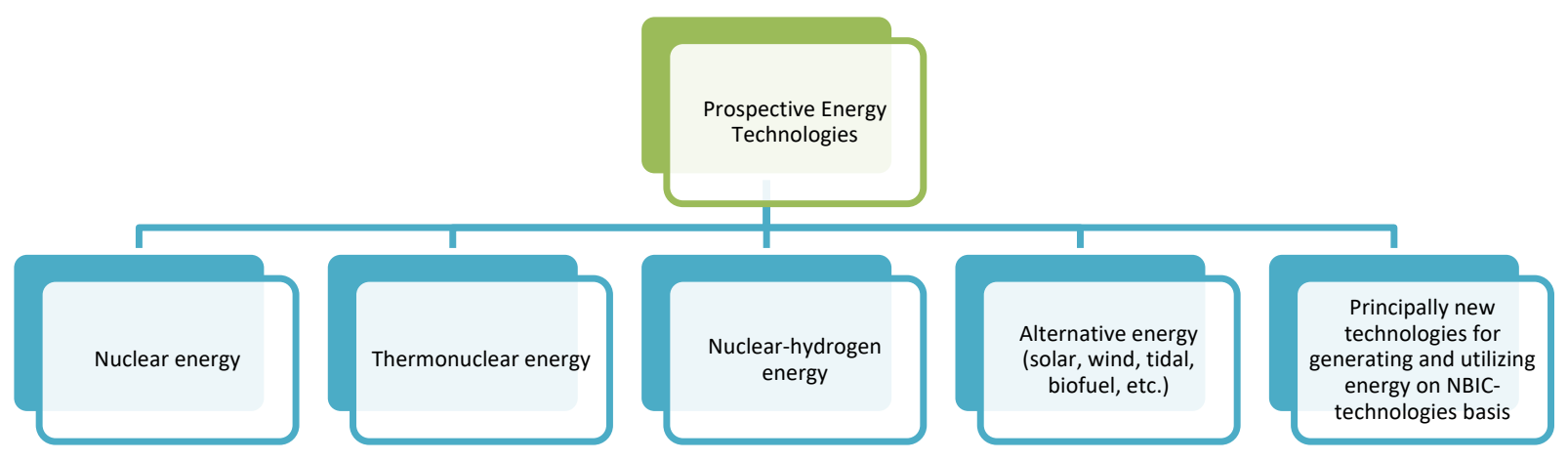

Figure 3. The most prospective energy technologies

Source: [8]

The most significant alternative to hydrocarbons is nuclear power based on the separation of uranium-235. On the other hand, the use of fission reactors (NPPs) inevitably creates two other global problems - the utilization of high-level spent fuel (HLW) and other radioactive waste, as well as nuclear safety. Today worldwide about 200 thousand tons of spent HLW, 1 million tons of waste of average activity and very active water and more than 10 million tons of waste of low activity have been accumulated. Each year, these figures increase by 5\% [13]. Since the early 1950s, it was unreasonably believed that the future of mankind was connected with the solution of the thermonuclear problem. The essence of thermonuclear energy is the use of energy released during fusion (synthesis) of light nuclei. The problem faced is confining the plasma and preventing contact with the walls of the camera. The advantages of nuclear fusion include:

- nuclear fusion can provide not only mankind's current energy needs (16 TB), but also produce a much greater amount of energy;

- as a fuel, it requires a very small amount of substances that are common in nature;

- thermonuclear plants are able to produce as much as $200 \mathrm{MWh}$ of electricity, which is equivalent to burning 70 tons of coal, even if it is not ideal, and a more efficient model of the installation will provide $2.5 \mathrm{GW}$ of fusion energy after the conversion and use of a certain particle for plasma heating and the work of superconducting electromagnets and other systems will provide $1.5 \mathrm{GW}$ of electrical output;

- high internal fusion energy;

- the absence of high-level radioactive waste that remains active for a long time [14].

The disadvantages of thermonuclear reactors are the technological complexity of the self-sustained fusion reaction, as well as the fact that there are no effective technical solutions that can convert the energy released during fusion into electricity. Examples of thermonuclear devices already in use in the developed world are: (1) The International Thermonuclear Experimental Reactor (ITER), a gigantic tokamak that will operate on the basis of deuterium-tritium fuel at a total cost of USD 10 billion (and may increase to USD 16 billion), which is being built in France; (2) National Ignition Facility (NIF or literally - "national ignition complex") - an alternative project worth USD 3.5 billion, which started in the USA in 2009. The complex includes 192 high-power lasers, the rays of which focus on a tiny sample of deuterium and tritium (although the US government is considering the future of 
the NIF more in the context of defense rather than energy). Today the problem of thermonuclear energy engineering is more technical and economic than physical, because for creation of real economically profitable power plants it is necessary to solve two principal tasks:

- the continuation of development of new materials that are able to withstand strict operating conditions;

- the creation of new technologies related to remote control, shell designs, fuel cycles, etc. $[7,8]$.

Andrea Rossi [15], the Italian inventor of the so-called E-Cat generator (or energy catalyst), promises LENR (low energy nuclear reactions) or "cold nuclear synthesis" to solve the global energy problem. Its fuel is nickel and hydrogen powder, and the source of energy is the nuclear reaction between them. As a result, the original compact version of the E-Sat generator was transferred on the basis of licensing agreements with China and South Korea for further large-scale production and sale at a unique low price of USD 500 for the reactor $[13,15]$. Hydrogen (atomic-hydrogen) power engineering, in particular, the production of metallic hydrogen and other exotic substances, is the next potentially effective direction of future energy development [8]. Perspective directions of use of metallic hydrogen are:

(1) in power engineering and microelectronics;

(2) safe storage of hydrogen fuel;

(3) research of various alloys of metallic hydrogen with heavier elements.

The main results of the research in this direction are presented by Matyushenko and colleagues $[3,7]$. Among the large variety of alternative energy sources, solar energy is primarily allocated. Renewable solar power has been technologically developed for many decades, and the efficiency of solar cells has increased significantly, however today solar energy still has not become a powerful energy resource. Unlike living nature, where solar energy accumulates through photosynthesis is still not available for artificial reproduction of the bioorganic structure of a green leaf, and this natural process is stimulated using a semiconductor structure $[7,8]$.

It has become obvious that systems that mimic objects of nature can be done by "launching the future" on the basis of the convergence of NBIC-technologies [16]. The main areas of the use of NBIC-technologies in the energy sector, in specific generation (conversion, production), accumulation, transfer and conservation of energy, include [17]:

- photovoltaic (solar cells), hydrogen (fuel elements) transformation, thermoelectricity (thermoelectric devices) Improvement of hydrocarbon energy (catalysts, additives);

- LEDs - Significant energy savings can be obtained by a transition to LED technology, including using organic OLED LEDs based on various forms of green fluorescent protein (GFP) that can also be used to create monitors, televisions, different kinds of displays, and more. GFPs are completely safe for the environment and require very little energy.

Considering Russia's aggression, for Ukraine, the problem of survival and sustainable development is directly related to the trends of world energy and the need to minimize dependence on hydrocarbons, may have the opportunity to become an energy-independent state through the improvement of nuclear technology and the use of unconventional energy sources. The National Academy of Sciences of Ukraine has provided scientific and technical support for nuclear power engineering, has created the Nuclear Physics and Energy Department of the National Academy of Sciences of Ukraine (NASU). One of the most important tasks has been the active study of perspective directions of development of nuclear energy in Ukraine and the development of appropriate proposals for the State Energy Strategy $[18,19]$. The results of the programmes execution are listed in Table 5.

Table 5. The most significant results of the NASU target comprehensive programs for scientific research on nuclear energy

\begin{tabular}{|c|l|l|l|}
\hline Year & $\begin{array}{c}\text { Sector of } \\
\text { the } \\
\text { program }\end{array}$ & \multicolumn{1}{|c|}{ The most significant result } & Practical utility \\
\hline $2004-$ & $\begin{array}{l}\text { Nuclear } \\
\text { energy }\end{array}$ & $\begin{array}{l}\text { promising results of research, ready for } \\
\text { further implementation, including the } \\
\text { technologies of obtaining new titanium } \\
\text { based metallurgy materials for spent fuel } \\
\text { tanks and production of hafnium of } \\
\text { nuclear purity for neutron-absorbing } \\
\text { elements, were obtained. }\end{array}$ & \\
\cline { 1 - 1 } $2011-$ & & $\begin{array}{l}\text { methods of high-frequency creation and } \\
\text { heating of plasma were developed; }\end{array}$ & $\begin{array}{l}\text { new methods of application of functional } \\
\text { coatings; }\end{array}$ \\
\hline
\end{tabular}




\begin{tabular}{|c|c|c|c|}
\hline & & $\begin{array}{l}\text { the behavior of energetic particles in } \\
\text { magnetic traps was investigated; } \\
\text { new methods of diagnostics of high- } \\
\text { temperature plasma have been } \\
\text { developed; } \\
\text { carried out experimental studies of the } \\
\text { behavior of structural materials of the first } \\
\text { wall and the diverter in the conditions of } \\
\text { extreme corpuscular and energy loads that } \\
\text { are inherent in the thermocouple reactor. }\end{array}$ & $\begin{array}{l}\text { modification of materials by powerful } \\
\text { currents of the plasma; } \\
\text { plan-coagulation sources of extreme } \\
\text { ultraviolet and X-ray radiation; } \\
\text { plasma ozonizers; } \\
\text { low-temperature plasma ozone-ultrasound } \\
\text { sterilizers; } \\
\text { helicopter technical sources; } \\
\text { plasmochemical reactors; vaporplastic } \\
\text { waste recycling technology; } \\
\text { the creation of new, promising } \\
\text { environmentally friendly, plasma } \\
\text { technologies for industry, medicine, rural } \\
\text { society and environmental protection }\end{array}$ \\
\hline
\end{tabular}

Source: $[18,19]$

Ukraine has also joined the international thermonuclear program by signing an Agreement on Cooperation between the Cabinet of Ministers of Ukraine and the European Atomic Energy Community in the field of controlled thermonuclear fusion, ratified by the Law of Ukraine of March 7, 2002, No. 3104-III (3104-14), according to which the main fields of cooperation include:

- experimental and theoretical studies of plasma content, transfer, heating and plasma control processes (including the development of appropriate high-frequency systems) and diagnostics in toroid magnetic devices;

- studies on plasma theory, in particular, the physics of fast ions and alpha particles in toroidal magnetic devices, and the study of turbulent plasma and nonlinear wave interactions in plasma;

- thermonuclear fusion technology;

- Applied Plasma Physics;

- policy on programs and plans [20].

However, as Ukraine was not formally involved in the unification of the countries involved in the construction of the reactor, its participation has been limited to solving auxiliary tasks within the framework of cooperation with the laboratories of Europe and Russia. In 2013, the Presidium of the National Academy of Sciences of Ukraine approved the Conception of the Target Complex Program of the National Academy of Sciences of Ukraine "Prospective studies on plasma physics, controlled thermonuclear fusion and plasma technologies" for 20142016 [22]. The main objective of this program is to increase the efficiency of research in plasma physics, controlled thermonuclear fusion (CTC) and plasma technologies aimed at identifying new physical principles of the structure of complex plasma systems and on this basis creating the physical foundations of new high-and low-temperature plasma technologies.

Table 6. The most significant results of the NASU target comprehensive programs for scientific research on thermonuclear energy

\begin{tabular}{|c|c|c|c|}
\hline Year & $\begin{array}{c}\text { Sector of } \\
\text { the } \\
\text { program }\end{array}$ & The most significant result & Practical utility \\
\hline $\begin{array}{l}2014- \\
2016\end{array}$ & $\begin{array}{l}\text { Thermo- } \\
\text { nuclear } \\
\text { energy }\end{array}$ & $\begin{array}{l}\text { realization of a number of projects in the following } \\
\text { areas of research: } \\
\text { - fundamental problems of plasma theory; } \\
\text { - controlled thermonuclear fusion; } \\
\text { - plasma electronics and collective methods of } \\
\text { accelerating charged particles; } \\
\text { - low temperature plasma and technology based on } \\
\text { it; } \\
\text { - plasmodynamics; } \\
\text { - cosmic plasma }\end{array}$ & $\begin{array}{l}\text { Modeling of physical processes in } \\
\text { large thermonuclear installations } \\
\text { with } \\
\text { diverter configurations such as } \\
\text { ITER } \\
\text { One-dimensional analytic-on } \\
\text { model of diffusion-convective } \\
\text { transfer of charged nucleation } \\
\text { synthesis products in a toroidal } \\
\text { plasma } \\
\text { Experimental installation "Plasma- } \\
\text { Dyelle-Tricycle Multi-speed } \\
\text { Accelerator" Modeling of }\end{array}$ \\
\hline
\end{tabular}




\begin{tabular}{|l|l|l|}
\hline & & $\begin{array}{l}\text { peculiarities of the influence of } \\
\text { longitudinal magnetic field }\end{array}$ \\
\hline
\end{tabular}

Source: [22]

Today, all countries are looking for new efficient and environmentally friendly alternative energy sources. Among renewable energy sources hydrogen has a special place in solving this problem, both from the point of view of high specific energy intensity, and from the point of view of the absence of environmental pollution in its use, since it burns only oxygen and its byproduct is water. As a result, hydrogen energy is viewed today as the most realistic alternative to modern energy resources, which are largely based on the combustion of hydrocarbons. At the same time, hydrogen can be obtained from natural gas, coal, biomass and virtually all renewable and nontraditional types of energy resources. The development of modern technology of fuel cells (PCs) allows heatgenerating machines to convert hydrogen into electricity without polluting the environment. In order to solve the problems of the development of hydrogen energy, fundamentally new technological solutions are needed in the direction of obtaining, storing and using hydrogen.

To address these issues and engage in research with the wider scientific community during 1995-2005 a number of international and national programs on hydrogen energy were created. First of all, this was the initiative of the International Energy Agency (IEA), which supports more than 40 relevant international programs. International organizations such as the International Organization for Cooperation and Development (OECD), the International Partnership for the Advancement of Hydrogen Energy (IPHE), the World Energy Network (WE-NET) and others promote the development of hydrogen energy. Additionally, in 2003, the European Commission established the "Technology Platform for Hydrogen and Fuel Cells," which began operations in January 2004. A number of hydrogen projects have also been funded by the EU under the auspices of the 6th and 7th Framework Programs, as well as the Horizon 2020 Program.

To create the foundations of hydrogen energy research in Ukraine, the Resolution of the Presidium of the National Academy of Sciences of Ukraine dated December 29, 2010 No. 356 approved the Targeted Integrated Program "Hydrogen in Alternative Energy and New Technologies" for 2011-2015 [23].

The main results of this program's implementation from 2011-2015 for solving global problems were presented in the study [7, p. 518-523]. Thus, as a result of the program's implementation the following were established:

- scientific basis of new hydrogen production technologies based on the use of renewable energy sources, organic wastes, non-condensed solid fuels;

- laws of the interaction of hydrogen with light hydride-forming metals, intermetallides and composites on their basis, as well as the influence of atomic structure, electronic structure and surface condition on hydrogen adsorption characteristics of hydrogen storage materials were investigated;

- materials with a hydrogen content of more than $4 \mathrm{wt}$. \% that are capable of absorbing and releasing hydrogen in the conditions necessary for their use in road transport;

- developed new high-performance functional and construction materials for high-temperature oxide-ceramic fuel cells (PCs) and low-temperature PC-based polymeric membranes, ZrO2 monoblock ceramic fuel cells and improved electrode materials, new proton-conducting polymer membranes with increased thermal stability;

- experimental prototypes of said oxygen-hydrogen fuel cells were created and investigated;

- proposed technologies for the use of hydrogen processing materials in order to modify their structure, increase mechanical and other operational properties;

- scientific foundations of destructive hydrogenation-recombination of intermetallic compounds and alloys containing hydride-forming metal were developed, as well as principles of the assessment of the working capacity of structural materials during their operation in a hydrogen medium;

- fundamental research was carried out and methods for minimizing the harmful effects of hydrogen on welded joints were proposed.

The process of looking for new ways to use energy resources of renewable energy accumulated by living substances through photosynthesis such as, biofuel, which is of high importance nowadays. Soon approximately $10 \%$ of total energy consumption may be covered by means of the products of photosynthesis. During the implementation of integrated programs "Biomass as a fuel material" ("Biofuels") and "Biological resources and the newest bioconversion technologies" in 2007-2015. To expand the use of alternative fuels by the use of biofuel, the scientific institutions of the National Academy of Sciences of Ukraine continued to work on prospective bio-resources, development and implementation of the latest bioconversion technologies for the 
production of liquid biofuels and expansion of their use, improvement and development of the latest chemical technologies for the production of biodiesel, utilization of agricultural, forestry, food processing and household waste as raw materials for bio-fuels [6].

Modern achievements in the field of optoelectronics have led to the creation of LED light sources with energy efficiency, which is 8-12 times greater than the energy efficiency of incandescent lamps. The use of such sources can significantly reduce electricity consumption for lighting and maintenance of the electricity grid, increase environmental safety, simplify the creation of automated lighting control systems and light signal equipment. To ensure a significant reduction of electricity consumption for lighting, improve its quality, reduce the burden on the environment by developing and introducing into the economy of Ukraine a new technology of "solid" lighting the Resolution of the Cabinet of Ministers of Ukraine dated 07.09.2008 No. 632 "On Approval of the State Target Scientific and Technical the program with development and introduction of energy saving LED light sources and lighting systems on their basis" for 2009-2013, a production program was introduced lighting at [24, 25].

The most significant results of the implementation of this program for 2009-2013 for solving global problems are presented in the study [7, p. 524-530] and in Table 7 in the most generalized view.

Table 7. The most significant results of the NASU target comprehensive programs for scientific research on optoelectronics

\begin{tabular}{|c|c|c|c|}
\hline Year & $\begin{array}{c}\text { Sector of the } \\
\text { program }\end{array}$ & The most significant result & Practical utility \\
\hline $\begin{array}{l}2009- \\
2013\end{array}$ & Optoelectronics & $\begin{array}{l}\text { - Creation of materials, } \\
\text { technologies and methods of } \\
\text { control, thermoregulation of LED } \\
\text { light sources; } \\
\text { - Manufacture of LED emitters and } \\
\text { their systems; } \\
\text { - Creation of means of diagnostics } \\
\text { and certification of LED light } \\
\text { sources; } \\
\text { - Realization of pilot projects on } \\
\text { introduction of energy-saving LED } \\
\text { lighting systems }\end{array}$ & $\begin{array}{l}\text { Technology allowed: } \\
\text { - to organize the modern production of LED } \\
\text { light sources, which include: energy saving } \\
\text { LED lamps; lighting devices for the needs of } \\
\text { housing and communal services; special fire } \\
\text { and explosion-proof lamps for mines; street } \\
\text { light fixtures; ceiling light fixtures for } \\
\text { illumination of administrative buildings } \\
\text { (including budgetary institutions), industrial } \\
\text { objects; LED illumination systems for } \\
\text { illumination of buildings, constructions and } \\
\text { artistic-decorative purposes; special lighting } \\
\text { systems; lighting systems for transport; } \\
\text { - to ensure the industrial production of } \\
\text { energy-saving LED light sources, whose energy } \\
\text { consumption is } 8 \text { - } 12 \text { times less than that of } \\
\text { incandescent lamps, with a life span of over } 50 \\
\text { thousand hours; } \\
\text { - to save about } 400 \text { million kWh of electricity } \\
\text { per year for each million LED lamps. }\end{array}$ \\
\hline
\end{tabular}

Source: $[6,7]$

\section{Conclusions}

The paper shows that today, when mankind is faced with a range of global problems, the activity of the state and society should be aimed at solving these problems, the main problem related to the material sphere can be combined into four groups:

- depopulation and aging of population;

- lack of food and exhaustion of stocks of some types of raw materials;

- environmental problems, lack of fuel energy and energy saving;

- slowing down of scientific and technological progress and lagging behind the leading countries in transition to a new technological wave.

Since 1992, the first year for which data are available for Ukraine, the country has been ranked last with by far the worst energy security index scores of any country in the large energy user group. Its scores over the period from 1980 to 2016 averaged $177 \%$ higher than those for the OECD.

The authors have concluded that due to the exacerbation of energy and environmental problems, the prospect of the gradual exhaustion of fossil hydrocarbons in most countries of the world thereby raise the issue of the 
need for widespread use of the latest convergent technologies in the development of nuclear energy, the creation of thermonuclear energy and the increased use of renewable energy sources as well as the search for new efficient and environmentally tolerant energy carriers. It was shown that in 2004-2010 the State Program for Fundamental and Applied Research on the Issues of the Use of Nuclear Materials, Nuclear and Radiation Technologies in the Sphere of Economic Development was carried out to solve the problems of nuclear power of Ukraine (the actual level of funding for this program was about $52 \%$ of the prescribed amount). In 2011-2015, a complex program "Scientific and technical support for the development of nuclear energy and application of radiation technologies in the branches of economy" was carried out at the institutes of the National Academy of Sciences of Ukraine, in which a number of important applied developments were obtained, namely:

- new methods for the application of functional coatings; modification of materials by powerful plasma flows;

- plasma sources of intense extreme ultraviolet and X-ray radiation;

- plasma ozonizers;

- low-temperature plasma ozone-ultrasound sterilizers;

- helicoid technological sources; plasma chemistry reactors;

- steam-plasma technology of waste processing;

- creation of environmentally friendly plasma technologies for industry, medicine, agriculture and environmental protection.

It was determined that the scientific institutes of the National Academy of Sciences actively participate in joint research with EU and Russian laboratories on the development of technology for controlled thermonuclear fusion, including in 2014-2015 as part of the integrated program "Prospective studies in plasma physics, controlled thermonuclear fusion and plasma technologies ". The most important results were:

- gaining new knowledge about the physical phenomena occurring in high-temperature plasma, including its interaction with solid surfaces;

- development of the fundamental aspects of thermonuclear energy for the future;

- development of physical principles and equipment for advanced ion-plasma technologies for industrial processing of materials, environmental protection, agriculture, medicine, diagnostics of substances, etc.;

- development of plasma electronics, plasmodynamics and physical foundations of collective methods of accelerating charged particles; an impetus for the development of the high-tech manufacturing industry, which is currently almost completely imported.

It has been established that from 2006-2015 Ukraine continued intensive fundamental and applied research within the framework of the programs "Fundamental problems of hydrogen energy", as well as "Hydrogen in alternative energy and new technologies" on the development of technologies for hydrogen production, which included:

- the creation of appropriate materials and highly effective processes that can lead to a significant reduction in the cost of both hydrogen itself and auxiliary systems, especially fuel cells,

- promotion the widespread commercialization of hydrogen energy technologies;

- coordination with the general tendency of increasing use of alternative energy and maximum possible decentralization of energy supply.

\section{References}

[1] OECD Factbook 2013: economic, environmental and social statistics, OECD, Paris, 2013, p.235.

[2] K. McCormick, N. Kautto, The bioeconomy in Europe: an overview, Sustainability 5 (2013) 2589-2608.

[3] I. Matyushenko, I. Sviatukha, L. Grigorova-Berenda L., Modern Approaches to Classification of Biotechnology as a Part of NBIC-Technologies for Bioeconomy, British Journal of Economics, Management \& Trade 14 (4), 2016, 1-14. DOI: 10.9734/BJEMT/2016/28151

[4] I. Matyushenko, Prospects of development of converging technologies in countries of the world and Ukraine for solving global problem, Kharkiv, 2017. URL: http://international-relationstourism.karazin.ua/themes/irtb/resources/ 65fb0e95a8eb6db461e44a5e2285ebf2.pdf

[5] I. Matyushenko, I. Buntov, O. Khanova. The next economy in Ukraine: developing alternative energy with the help of NBIC-technologies. British Journal of Economics, Management \& Trade. 2015. Vol. 9 (2), P. 119. DOI: $10.9734 /$ BJEMT/2015/18567

[6] I. Matyushenko, I. Sviatukha, M.Loktionova, Biotechnological research in Ukraine for solving energy, medical-biological and medical-ecological problems in 2009-2015 taking into account the implementation of the Association Agreement with the EU, ACTA Innovations. 2018. no. 28. 49-71. DOI: 10.32933/Actalnnovations.28.6 
[7] I. Matyushenko. Rozrobka i vprovadzhennya konverhentnykh tekhnolohiy v Ukrayini v umovakh novoyi promyslovoyi revolyutsiyi: orhanizatsiya derzhavnoyi pidtrymky: monohrafiya. Kharkiv: FOP Aleksandrova K. M., 2016.

[8] I. Matyushenko, I. Buntov. Prospects for creating the next power engineering in Ukraine basing on commercial utilization of nanotechnologies/Challenges and prospects for economy innovative development: Materials of the XVI International scientific-practical conference. Simferopol. 2012, 341354.

[9] M. Kyzym, P. Pronoza, Sh. Omarov. A. Problemi ta tsIll rozvitku Ukrayini u svltl globalnih problem svltovoyi spllnoti: monograflya. Harklv: VD «INZhEK», 2010.

[10] M. Kizim, V. Ponomarenko, etc.. Osnovi stalogo rozvitku Harklvskoyioblastl do 2020 roku: monograflya. Harklv: VD «INZhEK», 2010.

[11] I. Matyushenko, M. Kezem. OtsInka globalnih I spetsiflchnih natslonalnih problem, scho potrebuyut virlshennya v Ukrayinl // Aktualnyie voprosyi razvitiya innovatsionnoy deyatelnosti: materialyi XVI mezhdunar. nauch.-prakt. konf. (Evpatoriya, 23-27 maya 2011 g.). Cimferopol: Minekonom. ARK, 2011, 30-38.

[13] V. Visotskiy. «Bridke kachenya» yadernoyi flziki ta mozhliviy progres svltovoyi energetiki. Dzerkalo tizhnya. 2014. \# 24. P.12.

[14] D. Yergin. The Fundamentals of Energy Security, Testimony, Committee on Foreign Affairs US House of Representatives, March 22, 2007. URL: http://www.ifri.org/files/Energie/NoteEstrada.pdf

[15] V.Visotskiy. Chi viroste blliy lebld Iz bridkogo kachenyati? Novl rezultati termoyadernih doslldzhen zdatnl kardinalno zmlniti stavlennya do yadernoyi energlyi, masshtablv yiyi virobnitstva I vikoristannya, Dzerkalo tizhnya, 2014, 45, P. 12.

[16] M. Kyzym, I. Matyushenko. Perspektivi rozvitku I komertslallzatslyi nanotehnologly v ekonomlkah krayin svltu ta Ukrayini: monograflya, Harklv: VD «INZhEK», 2011.

[17] Ryinok nano: ot nanotehnologiy - k nanoproduktam/red. G. L. Azoeva, M.: BINOM, Laboratoriya znaniy, 2011.

[18] Derzhavna programa fundamentalnih I prikladnih doslldzhen z problem vikoristannya yadernih materlallv ta yadernih I radlatslynih tehnologly u sferl rozvitku galuzey ekonomlki na 2004-2010 rr.: postanova KabInetu MInIstrlv Ukrayini vld 08.09.2004 \# 1165 // Baza danih «Zakonodavstvo Ukrayini/Verhovna Rada Ukrayini. URL: http://zakon4.rada.gov.ua/laws/show/1165-2004-p

[19] Tsllova kompleksna programa naukovih doslldzhen NAN Ukrayini «Naukovo-tehnlchniy suprovld rozvitku yadernoyi energetiki ta zastosuvannya radlatslynih tehnologly u galuzyah ekonomlki» na 2011-2012 rr.: postanova Prezidlyi NAN Ukrayini vld 17.11.2010 \# 319 // Baza danih «Normativnl akti NAN Ukrayini/Natslonalna akademlya nauk Ukrayini. URL: http://www1.nas.gov.ua/infrastructures/Legaltexts/nas/2010/regulations/OpenDocs/101117_319_conc ept.pdf

[20] Ugoda pro splvrobltnitstvo mIzh KabInetom MInIstrlv Ukrayini ta Evropeyskim splvtovaristvom z atomnoyi energlyi v galuzl kerovanogo termoyadernogo sintezu: zakon Ukrayini vld 07.03.2002 \# 3104-III (3104-14) // Baza danih "Zakonodavstvo Ukrayini/Verhovna Rada Ukrayini. URL: http://zakon4.rada.gov.ua/laws/show/994_152

[21] Kontseptslya tsllovoyi kompleksnoyi programi NAN Ukrayini «Perspektivnl doslldzhennya z flziki plazmi, kerovanogo termoyadernogo sintezu ta plazmovih tehnologly» na 2014-2016 rr.: postanova Prezidlyi NAN Ukrayini vld 18.03.2013 \# 115 // Baza danih «Normativnl akti NAN Ukrayini/Natslonalna akademlya nauk Ukrayini. URL: http://www1.nas.gov.ua/ infrastructures/Legaltexts/nas/2013/regulations/OpenDocs /130918_115_1.pdf

[22] Kontseptslya tsllovoyi kompleksnoyi programi naukovih doslldzhen NAN Ukrayini «FundamentalnI problemi vodnevoyi energetiki»: postanova Prezidlyi NAN Ukrayini vld 13.03.2006 \# 183 // Baza danih «Normativnl akti NAN Ukrayini/Natslonalna akademlya nauk Ukrayini. URL: http://www1.nas.gov.ua/infrastructures/Legaltexts/nas/2006/regulations/ OpenDocs/060630_183_an1.pdf

[23] Kontseptslya tsllovoyi kompleksnoyi programi «Voden v alternativnly energetitsl ta novltnlh tehnologlyah» na 2011-2015 rr.: postanova Prezidlyi NAN Ukrayini vld 29.12.2010 \# 356 // Baza danih «Normativnl akti NAN Ukrayini/Natslonalna akademlya nauk Ukrayini. URL: http://www1.nas.gov.ua/infrastructures/Legaltexts/nas/2010/regulations/OpenDocs/101229_356_conc ept.pdf.

[24] Pro shvalennya Kontseptslyi Derzhavnoyi tsllovoyi naukovo-tehnlchnoyi programi «Rozrobka I vprovadzhennya energozberlgayuchih svltlodlodnih dzherel svltla ta osvltlyuvalnih sistem na yih 
osnovl»: rozporyadzhennya Kablnetu MInlstrlv Ukrayini vld 09.04.2008 \# 612-r // Baza danih «Zakonodavstvo Ukrayini/Verhovna Rada Ukrayini. URL: http://zakon4.rada.gov.ua/laws/show/ 6122008-r

[25] Pro zatverdzhennya Derzhavnoyi tsllovoyi naukovo-tehnlchnoyi programi «Rozrobka I vprovadzhennya energozberlgayuchih svltlodlodnih dzherel svitla ta osvltlyuvalnih sistem na yih osnovl» na 2009-2013 rr.: postanova Kablnetu MInlstrlv Ukrayini vld 09.07.2008 \# 632 // Baza danih «Zakonodavstvo Ukrayini/Verhovna Rada Ukrayini. URL: http://zakon2.rada.gov.ua/laws/show/ 632-2008-p

[26] Kontseptslya tsllovoyi kompleksnoyi programi «Voden $v$ alternativnly energetitsl ta novltnlh tehnologlyah» na 2011-2015 rr.: postanova Prezidlyi NAN Ukrayini vld 29.12.2010 \# 356 // Baza danih «Normativnl akti NAN Ukrayini/Natslonalna akademlya nauk Ukrayini. URL: http://www1.nas.gov.ua/infrastructures/Legaltexts/nas/2010/regulations/OpenDocs/101229_356_conc ept.pdf.

[27] World Energy Trilemma 2017. World Energy Council. URL: https://www.worldenergy.org/wpcontent/uploads/2017/11/World-Energy-Trilemma-2017 Full-report WEB.pdf

[28] International index of energy security risk. Assessing risk in a global energy market. URL: https://www.globalenergyinstitute.org/sites/default/themes/bricktheme/pdfs/energyrisk intl 2018.pdf

[29] O. Belkova. Na cjomu gruntuyetsia enerhetychna bezbeka Ukrayiny. Dzerkalo tizhnya. 2018. URL: https://dt.ua/energy_market/na-chomu-gruntuyetsya-energetichna-bezpeka-ukrayini-290252_.html 